\title{
Effects of Oral L-carnitine and DL-carnitine Supplementation on Alloxan-Diabetic Rats
}

\author{
Roberto Barbosa Bazotte ${ }^{1}$ and Gisele Lopes-Bertolini ${ }^{2 *}$ \\ ${ }^{I}$ Departamento de Farmacologia e Terapêutica; Universidade Estadual de Maringá; 87020-900; Maringá - PR - \\ Brasil. ${ }^{2}$ Departamento de Ciências Básicas em Saúde; Faculdade de Medicina; Universidade Federal do Mato \\ Grosso; Av. Fernando Correa da Costa, 2367; 78060-900; Cuiabá - MT - Brasil
}

\begin{abstract}
The effect of oral L-carnitine (LC) or DL-carnitine (DLC) supplementation during one or four weeks (200 or 400 $\mathrm{mg} . \mathrm{kg}^{-1}$. day $\left.{ }^{-1}\right)$ in diabetic rats was investigated. After the supplementation period, the blood was collected for the evaluation of total (TC) and free L-carnitine (FC), glucose, total cholesterol, high-density lipoprotein cholesterol $(H D L-C)$, low-density lipoprotein cholesterol $(L D L-C)$ and triacylglycerol. Tissues were collected for the determination of TC and FC concentrations. The carnitine supplementation did not change levels of glucose, total cholesterol, HDL-C and LDL-C in the blood. Diabetic rats showed hypertriacylglycerolemia and decreased blood and tissue levels of FC and TC. Normalization of the blood triacylglycerol and increased blood and tissue levels of FC and TC were observed with the LC or DLC supplementation. However, the hyperglycemia remained unchanged. Thus, the reduction of blood triacylglycerol obtained with carnitine supplementation in the diabetic rats did not depend on an amelioration in the glycemia and was mediated partly at least by an increment of serum and tissue concentrations of FC and TC.
\end{abstract}

Key words: carnitine, diabetes, dietary supplementation, lipids, rat

\section{INTRODUCTION}

L-Carnitine (LC) belongs to a group of food factors known as non-nutrient supplements. It is a normal component of the diet, being found in the animal products and vegetables. It is synthesized in the body from the lysine and methionine (Leibovitz and Mueller 1993). Several clinical conditions of carnitine deficiency have been described, including the genetic deficiency of Lcarnitine, hemodialysis, muscular and liver disorders, kidney and cardiovascular diseases and diabetes mellitus (Proulx et al. 1997; Feng et al. 2001; Hong et al. 2002; Bellinghieri et al. 2003; Karlic and Lohninger 2004; Llias et al. 2004;
Guarnieri et al. 2007; Rajasekar and Anuradha 2007; Cha 2008; Bernard et al. 2008).

When there is deficiency of LC, a common feature appears to be the increased serum concentration of triacylglycerol (Famularo et al. 1993; Malaguarnera et al. 1999; Bellinghieri et al. 2003; Tanaka et al. 2004). Therefore, a relevant aspect of the LC supplementation is a lipid-lowering effect observed in the experimental animals (Brady et al. 1986; Bell et al. 1987; Maccari et al. 1987; Feng et al. 2001; Hong et al. 2002; Rajasekar and Anuradha 2007) and human (Bellinghieri et al. 2003; Llias et al. 2004; Guarnieri et al. 2007; Cha 2008; Bernard et al. 2008). On the other hand, diabetes promotes carnitine deficiency (Mamoulakis et al. 2004) and increased blood

*Author for correspondence: gisele_bertolini@ufmt.br 
triacylglycerol (Siqueira et al. 2006). However, studies investigating the effect of carnitine supplementation on the blood levels of triacylglycerol in type 1 diabetes are absent, not only in the human but also in the experimental animals.

Thus, considering that alloxan-diabetic rats is a suitable experimental animal model of type 1 diabetes and the fact that these rats show hypertriacylglycerolemia (Siqueira et al. 2006), this work investigated the effect of LC and DLcarnitine (DLC) supplementation on the blood levels of triacylglycerol in alloxan-diabetic rats. In addition, the free carnitine (FC) and total carnitine (TC) concentrations in the serum, liver, diaphragm and heart were evaluated.

\section{MATERIALS AND METHODS}

\section{Materials}

LC and DLC were purchased from the Ajinomoto Company (São Paulo, Brazil). Alloxan was obtained from the Sigma Chemical Company (Saint Louis, EUA). Reagents used to measure the FC and TC were obtained from the Sigma. Lab kits to measure glucose, cholesterol, high-density lipoprotein cholesterol (HDL-C), low-density lipoprotein cholesterol (LDL-C), triacylglycerol, alanine aminotransferase (ALT) and aspartate aminotransferase (AST) were obtained from the Labtest (Lagoa Santa, MG, Brazil).

\footnotetext{
Animals

Male Wistar rats obtained from the animal house, weighing 190-220 g (at 7-8 weeks of age) were used. All the studies involving the animals were approved by the Local Animal Ethics Committee (protocol number 008/2006 and approval number 042/2006). The rats had free access to water and commercial standard rodent chow. The animals were maintained under the controlled temperature $\left(23^{\circ} \mathrm{C}\right)$, humidity and $12 \mathrm{~h}$ light $/ 12 \mathrm{~h}$ dark cycle during the period of carnitine supplementation. The rodent chow (Nutrilab CR1, Curitiba, PR, Brazil) was composed by the protein (22\%), fibers (8\%), mineral (10\%), calcium (1.4\%) and phosphorus $(0.8 \%)$. Each kilogram of the product was enriched with the metionine $(300 \mathrm{mg})$, lysine $(100 \mathrm{mg})$, antioxidant $(100 \mathrm{mg})$, vitamin A (12.000 IU), vitamin D3 (1.800 IU), vitamin E (30 $\mathrm{mg})$, vitamin $\mathrm{C}(800 \mathrm{mg})$, vitamin $\mathrm{K} 3(3 \mathrm{mg})$,
}

vitamin B1 (5 mg), vitamin B2 (6 mg), vitamin B6 $(7 \mathrm{mg})$, vitamin B12 $(20 \mu \mathrm{g})$, niacine $(60 \mathrm{mg})$, pantotenic acid $(20 \mathrm{mg})$, folic acid $(1.0 \mathrm{mg})$, biotine $(0.05 \mathrm{mg})$, coline $(600 \mathrm{mg})$, iron $(50 \mathrm{mg})$, zinc $(60 \mathrm{mg})$, copper $(10 \mathrm{mg})$, iodine $(2 \mathrm{mg})$, manganese $(60 \mathrm{mg})$, selenium $(0.05 \mathrm{mg})$, cobalt $(1.5 \mathrm{mg})$. Carnitine deficiency was obtained by the induction of diabetes. For this purpose, the rats received an intravenous injection (caudal vein) of alloxan (40 mg. $\mathrm{kg}^{-1}$ ) as previously described (Siqueira et al. 2006). The control rats received an intravenous injection (caudal vein) of saline. After an additional week, a blood sample from the tail was collected for glycemia evaluation and all the rats with glycemia above $250 \mathrm{mg}^{-\mathrm{dL}^{-1}}$ were included in the diabetic group.

\section{Carnitine supplementation}

Diabetic and non-diabetic rats received LC or DLC dissolved in the water (200 or $400 \mathrm{mg} \cdot \mathrm{kg}^{-}$ ${ }^{1}$.day ${ }^{-1}$ ) during one or four weeks. During the supplementation period, body weight, water and food ingestion were measured. Moreover, after the supplementation period, all the rats were fasted (14 h) and killed by decapitation. The blood was collected for the evaluation of the $\mathrm{FC}$ and $\mathrm{TC}$ (Wieland et al. 1985), glucose (Bergmeyer and Bernt 1974), total cholesterol, HDL-C, LDL-C (Allain et al. 1974), triacylglycerol (Bucolo and David 1973), ALT and AST (Bergmeyer et al. 1978). After blood collection, the rats were submitted to laparotomy and the liver, heart and diaphragm muscle were collected and frozen in liquid nitrogen until the determination of the levels of FC and TC (Wieland et al. 1985).

\section{Statistical Analysis}

Data were analyzed by the ANOVA (one way and two way) with the software Graph Pad Prism 2. Values were reported as mean values $(\mathrm{M}) \pm$ standard error (SE). $\mathrm{P}<0.05$ was accepted for all the comparisons.

\section{RESULTS}

\section{Supplementation of non-diabetic rats}

The LC or DLC (200 or $\left.400 \mathrm{mg} \cdot \mathrm{kg}^{-1} \cdot \mathrm{day}^{-1}\right)$ supplementation during one or four weeks did not change the water and food intake, body weight or the blood levels of enzymes AST and ALT (not shown). In addition, the blood levels of glucose, 
total cholesterol, HDL-C, LDL-C and triacylglycerol also remained unchanged (Table 1). On the other hand, the serum concentrations of FC increased from the first week of LC or DLC supplementation (200 or $400 \mathrm{mg} \cdot \mathrm{kg}^{-1} \cdot \mathrm{day}^{-1}$ ). But, an increased serum concentration of TC was observed (Table 2) only after four weeks of LC or DLC supplementation (200 or $400 \mathrm{mg} \cdot \mathrm{kg}^{-1}$. day ${ }^{-1}$ ).

Table 1 - Blood levels of glucose, triacylglycerol (TG), total cholesterol (COL), high density lipoprotein cholesterol (HDL-C) and low density lipoprotein cholesterol (LDL-C) in non-diabetic rats supplemented during 1 or 4 weeks with L-carnitine (LC), DL-carnitine (DLC), 200 or $400 \mathrm{mg} \cdot \mathrm{kg}^{-1} \cdot \mathrm{day}^{-1}$, or not supplemented (CONT). Blood were obtained from $14 \mathrm{~h}$ fasted rats. The results are expressed as $\mathrm{M} \pm \mathrm{SE}$ of 7 animals.

\begin{tabular}{|c|c|c|c|c|c|c|c|}
\hline \multirow{2}{*}{$\begin{array}{l}\text { Period } \\
\text { (weeks) }\end{array}$} & \multirow{2}{*}{$\begin{array}{c}\text { Dose } \\
\left(\mathrm{mg}^{-k g^{-1}} \cdot \text { day }^{-1}\right)\end{array}$} & \multirow{2}{*}{ Group } & \multicolumn{5}{|c|}{ Blood levels (mg.dL ${ }^{-1}$ ) } \\
\hline & & & Glucose & TG & COL & HDL-C & LDL-C \\
\hline \multirow{3}{*}{1} & 0 & CONT & $58.5 \pm 2.4$ & $78.6 \pm 6.2$ & $95.0 \pm 3.8$ & $67.3 \pm 3.6$ & $10.3 \pm 1.2$ \\
\hline & 200 & LC & $53.0 \pm 3.2$ & $70.1 \pm 5.1$ & $90.6 \pm 6.2$ & $66.6 \pm 4.8$ & $10.7 \pm 1.9$ \\
\hline & 200 & DLC & $54.4 \pm 3.2$ & $74.8 \pm 7.8$ & $97.4 \pm 5.3$ & $68.6 \pm 3.1$ & $10.9 \pm 2.6$ \\
\hline \multirow{3}{*}{1} & 0 & CONT & $59.1 \pm 2.1$ & $78.0 \pm 9.9$ & $91.3 \pm 6.2$ & $64.4 \pm 4.2$ & $10.4 \pm 1.9$ \\
\hline & 400 & LC & $55.8 \pm 3.0$ & $69.7 \pm 3.1$ & $93.1 \pm 4.5$ & $63.0 \pm 4.1$ & $10.4 \pm 1.8$ \\
\hline & 400 & DLC & $60.4 \pm 2.9$ & $75.6 \pm 8.4$ & $89.4 \pm 4.2$ & $68.4 \pm 6.1$ & $11.9 \pm 2.4$ \\
\hline \multirow{3}{*}{4} & 0 & CONT & $54.8 \pm 4.8$ & $82.9 \pm 11.3$ & $92.9 \pm 5.0$ & $63.1 \pm 3.7$ & $9.7 \pm 1.7$ \\
\hline & 200 & LC & $56.0 \pm 4.3$ & $72.4 \pm 14.2$ & $87.8 \pm 3.5$ & $64.1 \pm 5.1$ & $9.8 \pm 2.0$ \\
\hline & 200 & DLC & $59.2 \pm 1.5$ & $82.9 \pm 8.9$ & $90.7 \pm 3.4$ & $64.9 \pm 4.8$ & $8.3 \pm 1.5$ \\
\hline \multirow{3}{*}{4} & 0 & CONT & $58.9 \pm 2.9$ & $81.7 \pm 5.1$ & $93.6 \pm 8.8$ & $60.9 \pm 2.2$ & $8.1 \pm 2.8$ \\
\hline & 400 & $\mathrm{LC}$ & $53.4 \pm 6.2$ & $70.9 \pm 14.1$ & $90.5 \pm 6.7$ & $64.5 \pm 2.1$ & $10.3 \pm 1.2$ \\
\hline & 400 & DLC & $53.2 \pm 4.4$ & $76.4 \pm 5.0$ & $90.7 \pm 4.1$ & $60.5 \pm 1.8$ & $8.7 \pm 2.7$ \\
\hline
\end{tabular}

Table 2 - Serum and tissue levels of free L-carnitine (FC) and total L-carnitine (TC) in non-diabetic rats supplemented during 1 or 4 weeks with L-carnitine (LC) or DL-carnitine (DLC), 200 or $400 \mathrm{mg}^{\mathrm{kg}} \mathrm{kg}^{-1}$.day ${ }^{-1}$, or not supplemented (CONT). Serum and tissues were obtained from $14 \mathrm{~h}$ fasted rats. The results are expressed as $\mathrm{M} \pm \mathrm{SE}$ of 7 animals. ${ }^{a}$ Dose of L-carnitine (LC) or DL-carnitine (DLC) expressed in mg.kg ${ }^{-1} \cdot \mathrm{day}^{-1}$. " Different of CONT group. $\mathrm{p}<0.05$ (ANOVA). ${ }^{\mathrm{b}}$ Different of DLC group. $\mathrm{p}<0.05$ (ANOVA).

\begin{tabular}{|c|c|c|c|c|c|c|c|}
\hline Sample & $\begin{array}{l}\text { Period } \\
\text { (weeks) }\end{array}$ & Parameter & CONT & LC 200 ${ }^{a}$ & DLC 200 ${ }^{a}$ & $\mathrm{LC} 400^{\mathrm{a}}$ & DLC 400 ${ }^{\mathrm{a}}$ \\
\hline \multirow{4}{*}{$\underset{\left(\mu \mathrm{mol} . \mathrm{L}^{-1}\right)}{\text { Serum }}$} & \multirow{2}{*}{1} & $\mathrm{FC}$ & $17.5 \pm 0.5$ & $23.4 \pm 1.3^{*}$ & $21.7 \pm 1.3^{*}$ & $24.6 \pm 1.4^{*}$ & $22.7 \pm 2.0^{*}$ \\
\hline & & $\mathrm{TC}$ & $42.8 \pm 0.9$ & $46.3 \pm 2.4$ & $44.2 \pm 2.7$ & $47.9 \pm 3.3$ & $46.9 \pm 3.4$ \\
\hline & \multirow[b]{2}{*}{4} & $\mathrm{FC}$ & $18.2 \pm 0.5$ & $26.3 \pm 1.4^{*}$ & $24.8 \pm 1.8^{*}$ & $27.6 \pm 1.5^{*}$ & $25.7 \pm 1.7^{*}$ \\
\hline & & $\mathrm{TC}$ & $41.6 \pm 1.0$ & $49.7 \pm 2.4^{*}$ & $48.2 \pm 2.3^{*}$ & $54.3 \pm 2.4^{*}$ & $52.2 \pm 2.7^{*}$ \\
\hline \multirow{4}{*}{$\begin{array}{c}\text { Liver } \\
\left(\mathrm{nmol.g}^{-1}\right)\end{array}$} & \multirow{2}{*}{1} & $\mathrm{FC}$ & $86.3 \pm 2.0$ & $109.3 \pm 2.3^{* b}$ & $93.6 \pm 2.4^{*}$ & $121.1 \pm 3.4^{* b}$ & $94.1 \pm 2.4^{*}$ \\
\hline & & $\mathrm{TC}$ & $225.4 \pm 3.3$ & $230.0 \pm 3.6$ & $223.1 \pm 3.0$ & $231.7 \pm 3.4$ & $228.9 \pm 3.4$ \\
\hline & \multirow[b]{2}{*}{4} & $\mathrm{FC}$ & $87.6 \pm 1.9$ & $123.1 \pm 3.5^{* b}$ & $101.4 \pm 1.8^{*}$ & $129.0 \pm 4.2^{* b}$ & $105.4 \pm 2.6^{*}$ \\
\hline & & $\mathrm{TC}$ & $224.0 \pm 4.1$ & $231.5 \pm 3.6$ & $226.2 \pm 3.7$ & $232.5 \pm 3.9$ & $229.3 \pm 4.0$ \\
\hline \multirow{4}{*}{$\begin{array}{c}\text { Diaphragm } \\
\left(\text { nmol.g }^{-1}\right)\end{array}$} & \multirow{2}{*}{1} & $\mathrm{FC}$ & $412.2 \pm 15.1$ & $437.5 \pm 10.8$ & $426.1 \pm 12.0$ & $439.7 \pm 14.2$ & $434.7 \pm 16.2$ \\
\hline & & $\mathrm{TC}$ & $536.9 \pm 18.9$ & $543.2 \pm 15.1$ & $541.3 \pm 14.9$ & $549.1 \pm 16.3$ & $546.4 \pm 17.2$ \\
\hline & \multirow[b]{2}{*}{4} & $\mathrm{FC}$ & $415.2 \pm 15.2$ & $471.3 \pm 18.5^{*}$ & $441.4 \pm 12.8$ & $495.1 \pm 12.6^{*}$ & $445.8 \pm 14.6$ \\
\hline & & $\mathrm{TC}$ & $541.3 \pm 17.9$ & $553.8 \pm 17.4$ & $550.7 \pm 13.9$ & $555.7 \pm 18.3$ & $552.5 \pm 13.4$ \\
\hline \multirow{4}{*}{$\begin{array}{c}\text { Heart } \\
\left(\mathrm{nmol}^{\left.-\mathrm{g}^{-1}\right)}\right.\end{array}$} & \multirow{2}{*}{1} & $\mathrm{FC}$ & $504.8 \pm 6.1$ & $515.7 \pm 6.6$ & $505.6 \pm 7.3$ & $521.8 \pm 12.9$ & $512.1 \pm 9.1$ \\
\hline & & $\mathrm{TC}$ & $634.1 \pm 17.4$ & $646.2 \pm 19.6$ & $641.3 \pm 19.4$ & $650.8 \pm 17.6$ & $650.3 \pm 19.8$ \\
\hline & \multirow{2}{*}{4} & $\mathrm{FC}$ & $506.1 \pm 7.1$ & $555.8 \pm 7.4^{*}$ & $521.6 \pm 10.4$ & $571.8 \pm 9.5^{*}$ & $524.4 \pm 12.1$ \\
\hline & & $\mathrm{TC}$ & $635.3 \pm 18.1$ & $651.1 \pm 16.4$ & $635.7 \pm 19.6$ & $650.0 \pm 19.8$ & $647.9 \pm 17.7$ \\
\hline
\end{tabular}


Liver FC levels also increased from the first week of LC or DLC supplementation (200 or $400 \mathrm{mg} . \mathrm{kg}$ ${ }^{1} \cdot$ day $\left.^{-1}\right)$. However, the levels of FC were higher in the livers of the rats supplemented during one or four weeks with LC (200 or $400 \mathrm{mg} \cdot \mathrm{kg}^{-1}$. day ${ }^{-1}$ ) than those supplemented with DLC. In contrast with $\mathrm{FC}$, the liver concentration of TC remained unchanged for all doses or duration of LC or DLC supplementation (Table 2).

In the diaphragm and heart, increased levels of FC were observed after four weeks of LC supplementation (200 or $400 \mathrm{mg} \cdot \mathrm{kg}^{-1} \cdot \mathrm{day}^{-1}$ ). In contrast, the FC levels in the diaphragm and heart remained unchanged for all the doses or duration of DLC supplementation. Moreover, the TC levels remained unchanged for all the doses or duration of LC or DLC supplementation (Table 2).

\section{Supplementation of alloxan-diabetic rats}

The supplementation (one or four weeks) with LC or DLC (200 or $400 \mathrm{mg} \cdot \mathrm{kg}^{-1} \cdot \mathrm{day}^{-1}$ ) did not change the water and food intake, body weight or the blood levels of the enzymes AST and ALT (not shown). Moreover, the blood levels of glucose, total cholesterol, HDL-C and LDL-C also remained unchanged (Table 3). However, decreased triacylglycerol levels were observed (Table 3) after four weeks of LC or DLC supplementation (400 mg. $\left.\mathrm{kg}^{-1} \cdot \mathrm{day}^{-1}\right)$. Before LC or DLC supplementation, diabetic rats showed decreased FC and TC levels in the serum, diaphragm and heart (Table 4). FC blood levels increased from the first week of LC or DLC supplementation (200 or 400 mg.kg ${ }^{-1}$.day ${ }^{-1}$ ).

Table 3 - Blood levels of glucose, triacylglycerol (TG), total cholesterol (COL), high density lipoprotein cholesterol (HDL-C) and low density lipoprotein cholesterol (LDL-C) in diabetic rats supplemented during 1 week $\left(200 \mathrm{mg}^{-\mathrm{kg}^{-}}\right.$ ${ }^{1}$.day ${ }^{-1}$ ) or 4 weeks (400 mg. $\mathrm{kg}^{-1}$.day ${ }^{-1}$ ) with L-carnitine (LC), DL-carnitine (DLC) or not supplemented (CONT). Blood were obtained from $14 \mathrm{~h}$ fasted rats. The results are expressed as $\mathrm{M} \pm \mathrm{SE}$ of 7 animals. * Different of CONT group. $\mathrm{p}<0.05$ (ANOVA).

\begin{tabular}{|c|c|c|c|c|c|c|c|}
\hline \multirow{2}{*}{ Weeks } & \multirow{2}{*}{$\begin{array}{c}\text { Dose } \\
\left(\mathrm{mg}^{-k^{-1}} \cdot \mathrm{day}^{-1}\right)\end{array}$} & \multirow{2}{*}{ Group } & \multicolumn{5}{|c|}{ Blood levels (mg.dL $\left.{ }^{-1}\right)$} \\
\hline & & & Glucose & TG & COL & HDL-C & LDL-C \\
\hline \multirow{3}{*}{1} & 0 & CONT & $374.6 \pm 19.0$ & $258.9 \pm 43.6$ & $127.4 \pm 4.9$ & $73.9 \pm 3.8$ & $9.8 \pm 2.4$ \\
\hline & 200 & $\mathrm{LC}$ & $367.5 \pm 27.3$ & $229.2 \pm 39.6$ & $117.6 \pm 11.1$ & $75.2 \pm 5.2$ & $10.2 \pm 1.4$ \\
\hline & 200 & DLC & $395.2 \pm 25.5$ & $233.4 \pm 38.3$ & $124.3 \pm 4.2$ & $67.9 \pm 3.7$ & $8.4 \pm 3.2$ \\
\hline \multirow{3}{*}{4} & 0 & CONT & $368.1 \pm 27.7$ & $223.8 \pm 33.4$ & $119.7 \pm 5.0$ & $73.7 \pm 5.1$ & $10.4 \pm 2.3$ \\
\hline & 400 & $\mathrm{LC}$ & $363.7 \pm 38.1$ & $79.2 \pm 9.5^{*}$ & $118.6 \pm 4.8$ & $75.3 \pm 4.3$ & $9.0 \pm 2.0$ \\
\hline & 400 & DLC & $402.3 \pm 13.0$ & $96.3 \pm 16.9^{*}$ & $121.5 \pm 3.5$ & $71.2 \pm 4.2$ & $10.2 \pm 2.8$ \\
\hline
\end{tabular}

Table 4 - Serum and tissue levels of free L-carnitine (FC) and total L-carnitine (TC) in diabetic and non-diabetic rats. The animals were fasted $(14 \mathrm{~h})$ before the blood and tissue collection. The results are expressed as $\mathrm{M} \pm \mathrm{SE}$ of 7 animals. * Different of non-diabetic group. $\mathrm{p}<0.05$ (ANOVA).

\begin{tabular}{clcccc}
\hline Parameter & Groups & $\begin{array}{c}\text { Serum } \\
\left(\boldsymbol{\mu m o l . L ^ { - 1 } )}\right.\end{array}$ & $\begin{array}{c}\text { Liver } \\
\left(\mathbf{n m o l . g} \mathbf{g}^{-1}\right)\end{array}$ & $\begin{array}{c}\text { Diaphragm } \\
\left(\mathbf{n m o l . g} \mathbf{- 1}^{-1}\right)\end{array}$ & $\begin{array}{c}\text { Heart } \\
(\mathbf{n m o l . g})\end{array}$ \\
\hline \multirow{2}{*}{ LC } & Non-diabetic & $17.5 \pm 0.5$ & $86.3 \pm 1.9$ & $412.6 \pm 15.1$ & $504.8 \pm 6.1$ \\
& Diabetic & $10.3 \pm 1.5^{*}$ & $110.7 \pm 4.0^{*}$ & $349.2 \pm 19.3^{*}$ & $445.8 \pm 18.0^{*}$ \\
\multirow{2}{*}{ TC } & Non-diabetic & $42.8 \pm 0.9$ & $225.4 \pm 3.3$ & $536.9 \pm 18.9$ & $634.1 \pm 17.4$ \\
& Diabetic & $35.2 \pm 1.1^{*}$ & $263.4 \pm 11.0^{*}$ & $470.1 \pm 17.2^{*}$ & $572.7 \pm 18.3^{*}$ \\
\hline
\end{tabular}

However, serum concentrations of TC increased after four weeks of supplementation with 400 mg.kg ${ }^{-1} \cdot$ day $^{-1}$ of LC or DLC (Table 5). Furthermore, liver, diaphragm and heart, showed increased concentrations of FC and TC after four weeks of LC or DLC supplementation (400 mg.kg${ }^{1}$.day $\left.{ }^{-1}\right)($ Table 5). 
Table 5 -Serum and tissue levels of free carnitine (FC) and total L-carnitine (TC) in diabetic rats supplemented during 1 or 4 weeks with L-carnitine (LC) or DL-carnitine (DLC), 200 or $400 \mathrm{mg} \cdot \mathrm{kg}^{-1} \cdot \mathrm{day}^{-1}$, or not supplemented (CONT). Blood and tissues were obtained from $14 \mathrm{~h}$ fasted rats. The results are expressed as $\mathrm{M} \pm \mathrm{SE}$ of 7 animals. ${ }^{\mathrm{a}}$ Dose of L-carnitine (LC) or DL-carnitine (DLC) expressed in $\mathrm{mg}^{\mathrm{kg}} \mathrm{kg}^{-1}$.day ${ }^{-1}$. * Different of CONT group. $\mathrm{p}<0.05$ (ANOVA).

\begin{tabular}{|c|c|c|c|c|c|c|}
\hline Sample & Parameter & CONT & 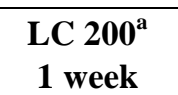 & $\begin{array}{c}\text { DLC 200 } \\
1 \text { week }\end{array}$ & $\begin{array}{l}\mathrm{LC} \mathrm{400}{ }^{\mathrm{a}} \\
4 \text { weeks }\end{array}$ & $\begin{array}{c}\text { DLC 400 a } \\
4 \text { weeks }\end{array}$ \\
\hline \multirow{2}{*}{$\begin{array}{c}\text { Serum } \\
\left(\mu \mathrm{mol} . \mathrm{L}^{-1}\right)\end{array}$} & $\mathrm{FC}$ & $10.3 \pm 1.5$ & $18.9 \pm 1.6^{*}$ & $17.0 \pm 1.6^{*}$ & $21.6 \pm 1.7 *$ & $18.6 \pm 1.9 *$ \\
\hline & $\mathrm{TC}$ & $35.2 \pm 1.1$ & $38.5 \pm 2.0$ & $36.7 \pm 1.9$ & $44.2 \pm 1.9 *$ & $41.8 \pm 1.9 *$ \\
\hline \multirow{2}{*}{$\begin{array}{c}\text { Liver } \\
\left(\mathrm{nmol.g}^{-1}\right)\end{array}$} & FC & $110.7 \pm 4.0$ & $118.6 \pm 4.4$ & $115.5 \pm 4.6$ & $137.8 \pm 4.3^{*}$ & $130.9 \pm 4.6^{*}$ \\
\hline & $\mathrm{TC}$ & $263.4 \pm 11.0$ & $281.6 \pm 12.6$ & $274.6 \pm 13.5$ & $339.2 \pm 16.9 *$ & $320.3 \pm 15.7 *$ \\
\hline \multirow{2}{*}{$\begin{array}{l}\text { Diaphragm } \\
\left(\mathrm{nmol.g}^{-1}\right)\end{array}$} & $\mathrm{FC}$ & $349.2 \pm 19.3$ & $381.6 \pm 17.2$ & $375.0 \pm 16.1$ & $425.7 \pm 20.1 *$ & $419.0 \pm 19.0 *$ \\
\hline & $\mathrm{TC}$ & $470.1 \pm 17.2$ & $512.3 \pm 16.4$ & $496.1 \pm 15.2$ & $541.0 \pm 18.0^{*}$ & $535.0 \pm 16.6^{*}$ \\
\hline \multirow{2}{*}{$\begin{array}{c}\text { Heart } \\
\left(\mathrm{nmol.g}^{-1}\right)\end{array}$} & $\mathrm{FC}$ & $445.8 \pm 18.0$ & $462.6 \pm 20.6$ & $459.2 \pm 22.2$ & $525.7 \pm 25.2 *$ & $519.9 \pm 24.3 *$ \\
\hline & $\mathrm{TC}$ & $572.7 \pm 18.3$ & $610.2 \pm 20.7$ & $599.5 \pm 21.4$ & $660.6 \pm 23.6^{*}$ & $648.2 \pm 21.6^{*}$ \\
\hline
\end{tabular}

\section{DISCUSSION}

In agreement with the previous studies (Bell et al. 1987; Bobyleva-Guarriero et al. 1988, Bell et al. 1992), the supplementation (one or four weeks) with LC or DLC ( 200 or $400 \mathrm{mg} \cdot \mathrm{kg}^{-1} \cdot \mathrm{day}^{-1}$ ) did not modify the blood lipids in the non-diabetic rats (Table 1). The absence of effect of LC or DLC could not be attributed to the lack of intestinal absorption, since an increased serum levels of FC were found in the non-diabetic rats supplemented with LC or DLC (Table 2). Thus, in spite the fact that $\beta$-oxidation depended on the activity of the carnitine dependent transport of fatty acids (Kuroda et al. 1996; Longo et al. 1996), the increased availability of LC or DLC did not change the blood lipid levels in the non-diabetic rats. However, in contrast with these results, LC administration decreased the blood lipids in the animals and humans. However, this effect occurred if the blood levels of cholesterol and/or triacylglycerol were elevated due to the metabolic disorders or dietary manipulations (Hoppel and Brass 1978; Paulson and Shug 1981; Pola et al. 1983; Vacha et al. 1983; Brady et al. 1986; Bell et al. 1987; Maccari et al. 1987; Shimura and Hasegawa 1993). In the non-diabetic rats, the blood levels of FC increased from the first week of LC or DLC supplementation (200 or 400 mg.kg${ }^{1} \cdot$ day $\left.^{-1}\right)$. However, an increased blood level of TC was observed (Table 2) after four weeks of LC or DLC supplementation (200 or $400 \mathrm{mg} \cdot \mathrm{kg}^{-1}$. $\mathrm{day}^{-1}$ ). Thus, the duration of supplementation, but not the daily dose was crucial to increase the blood levels of TC. On the other hand, there was no change in the concentration of the TC in the liver, diaphragm and heart (Table 2) one or four weeks of the supplementation (200 or $400 \mathrm{mg} \cdot \mathrm{kg}^{-1}$.day ${ }^{-1}$ ).

In the non-diabetic rats supplemented with LC or DLC (200 or $400 \mathrm{mg} \cdot \mathrm{kg}^{-1}$. day ${ }^{-1}$ ) for one or four weeks, higher liver concentration of $\mathrm{FC}$ were observed (Table 2). However, the levels of FC in the liver was higher in the rats supplemented with LC (200 mg. $\mathrm{kg}^{-1}$. day $\left.{ }^{-1}\right)$ than the rats supplemented with DLC (200 or $\left.400 \mathrm{mg} \cdot \mathrm{kg}^{-1} \cdot \mathrm{day}^{-1}\right)$.

In the non-diabetic rats, the $\mathrm{FC}$ concentration in the diaphragm and heart tissue did not differ between the groups after one week of supplementation (200 or $400 \mathrm{mg} \cdot \mathrm{kg}^{-1} \cdot \mathrm{day}^{-1}$ ). However, after four weeks of supplementation, the concentrations of $\mathrm{FC}$ in the groups supplemented with LC (200 or $\left.400 \mathrm{mg} \cdot \mathrm{kg}^{-1} \cdot \mathrm{day}^{-1}\right)$ were higher than the DLC group (Table 2). Thus, the duration of the supplementation, but not the daily dose, was crucial to increase the levels of FC in the diaphragm and heart. This result also suggested that the D-isomer influenced the liver carnitine uptake, but in lesser extent than in the diaphragm. Therefore, as described in other studies (Paulson and Shug 1981; Bremer 1983), the liver pool of LC appeared to be less affected by the D-carnitine (DC). Therefore, the results from non-diabetic rats suggested the existence of selectivity to the LC isomer (Huth and Shug 1980; Vary and Neely 1982; Lopes et al. 2003). In agreement with this proposition, several studies showed the existence of a competitive inhibition of the LC uptake by the DC (Yokogawa et al. 1999; Georges et al. 2000. 
Since diabetic rats showed reduced levels of the FC and TC in the plasma, kidney, heart and muscles (Brooks et al. 1985; Rodrigues et al. 1988; Rodrigues et al. 1990; Reddi et al. 1991) and the supplementation with LC restored the normal concentration of carnitine in these tissues (Marzo et al. 1993; Malone et al. 1999), they could be used as an animal model of carnitine deficiency and carnitine supplementation. In agreement with this proposition, lower levels of FC and TC (serum, diaphragm, heart and muscles) were found, before the supplementation with the LC or DLC (diabetic vs. non-diabetic rats).

Alternatively, diabetic rats supplemented with the LC or DLC during one week $\left(200 \mathrm{mg} \cdot \mathrm{kg}^{-1} \cdot \mathrm{day}^{-1}\right)$ or four weeks (400 mg.kg-1 $\mathrm{day}^{-1}$ ) showed higher concentration of FC than non-supplemented diabetic rats. But, the TC levels in the blood, liver, diaphragm and heart only increased after four weeks of LC or DLC (400 mg. $\left.\mathrm{kg}^{-1} \cdot \mathrm{day}^{-1}\right)$ supplementation (Table 5), suggesting that the duration of supplementation influenced the serum and tissue levels of the TC in the diabetic rats.

Carnitine deficiency promotes changes in lipid metabolism (Famularo et al. 1993). But LC supplementation restores the lipid metabolism, including reduction of blood levels of triacylglycerol, phospholipids and free fatty acids (Rebouche 1992; Dayanandan et al. 1994; Ji et al. 1996; Llias et al. 2004; Guarnieri et al. 2007). In agreement with these studies, supplementation with LC or DLC (400 mg. $\mathrm{kg}^{-1}$. day ${ }^{-1}$ ) during four weeks normalized the increased serum triacylglycerol concentrations of the diabetic rats but did not change the hyperglycemia (Table 3 ). Thus, it was concluded that the reduction of blood triacylglycerol obtained with the LC or DLC supplementation in the diabetic rats did not depend on an amelioration in the glycemia and was mediated partly at least by an increment of serum and tissue concentrations of the FC and TC, particularly in the liver. Furthermore, these findings suggested that the LC or DLC supplementation could be recommended in the patients with type 2 diabetes with high blood levels of triacylglycerol. However, additional studies will be necessary to confirm this suggestion.

\section{REFERENCES}

Allain CC, Poon LS, Chan CS, Richmond W, Fu PC. Enzymatic determination of total serum cholesterol. Clin Chem. 1974; 20: 470-475.

Bell FP, Raymond TL, Patnode PL. The influence of diet and carnitine supplementation on plasma carnitine, cholesterol and triglyceride in WHHL (Watanabe Heritable Hyperlipidemic), Netherland Dwarf and New Zealand rabbits (Oryctolagus cuniculus). Comp Biochem Physiol. 1987; 87: 587591.

Bell FP, Vidmar TJ, Raymond TL. L-carnitine administration and withdrawal affect plasma and hepatic carnitine concentrations, plasma lipid and lipoprotein composition, and in vitro hepatic lipogenesis from labeled mevalonate and oleate in normal rabbits. J Nutr. 1992; 122: 959-966.

Bellinghieri G, Santoro D, Calvani M, Mallamace A, Savica V. Carnitine and hemodialysis. Am J Kidney Dis. 2003; 41: S116-S122.

Bergmeyer HU, Bernt E. Determination of glucose with glucose-oxidase and peroxidase. Editors: H. U. Bergmeyer. In: Methods of enzymatic analysis. New York: Academic Press; 1974. 1205-1215.

Bergmeyer HU, Scheibe P, Wahlefeld AW. Optimization of methods for aspartate aminotransferase and alanine aminotransferase. Clin Chem. 1978; 24: 58-73.

Bernard A, Regault C, Mazue F, Le Borgne F, Demarquoy J. L-carnitine supplementation and physical exercise restore age-associated decline in some mitochondrial functions in the rat. $J$ Gerontol A Biol Sc Med Sci. 2008; 63: 1027-1033.

Bobyleva-Guarriero V, Iannone A, Bellei M, Muscatello U. Effects of single or multiple doses of L-carnitine on liver energetic metabolism of rats forced to run. J Sports Med. 1988; 28: 298-303.

Brady LJ, Knoeber CM, Hoppel CL, Leathers CW, Mcfarland D, Brady PS. Pharmacologic action of Lcarnitine in hypertriglyceridemia in obese Zucker rats. Metabolism 1986; 35: 555-562.

Bremer J. Carnitine - metabolism and functions. Physiol Rev. 1983; 63: 1420-1480.

Brooks SD, Bahl JJ, Bressler R. Carnitine in the streptozotocin-diabetic rat. J Nutr. 1985; 115: 12671273.

Bucolo G, David H. Quantitative determination of serum triglycerides by the use of enzymes. Clin Chem. 1973; 19: 476-482.

Cha YS. Effects of L-carnitine on obesity, diabetes, and as an ergogenic aid. Asia Pac J Clin Nutr. 2008; 17: S306-S308. 
Dayanandan A, Kumar P, Kalaiselvi T, Panneerselvam C. Effect of L-carnitine on the blood lipid composition in atherosclerotic rats. J Clin Biochem Nutr. 1994; 17: 81-87.

Famularo G, Tzantzoglou S, Santini G, Trinchieri V, Moretti S, Koverech A, et al. L-carnitine: a partner between immune response and lipid metabolism? Mediators Inflamm. 1993; 2: S29-S32.

Feng Y, Guo C, Wei J, Yang J, Ge Y, Gao L. Necessity of carnitine supplementation in semistarved rats fed a high-fat diet. Nutr J. 2001; 17: 628-631.

Georges B, Le Borgne F, Galland S, Isoir M, Ecosse D, Grand-Jean F, et al. Carnitine transport into muscular cells. Inhibition of transport and cell growth by mildronate. Biochem Pharmacol. 2000; 59: 13571363.

Guarnieri G, Biolo G, Vinci P, Massolino B, Barazzoni R. Advances in carnitine in chronic uremia. J Ren Nutr. 2007; 17: 23-29.

Hong YM, Kim HS, Yoon HR. Serum lipid and fatty acid profiles in adriamycin-treated rats after administration of L-carnitine. Pediatr Res. 2002; 51: 249-255.

Hoppel CL, Brass EP. Carnitine metabolism in the fasting rat. J Biol Chem. 1978; 253, 2688-2693

Huth PJ, Shug A. Properties of carnitine transport in rat kidney cortex. Biochim Biophys Acta 1980; 602: 621634.

Ji H, Bradley TM, Tremblay GC. Atlantic salmon (Salmo salar) fed L-carnitine exhibit altered intermediary metabolism and reduced tissue lipid, but no change in growth rate. J Nutr. 1996; 126: 19371950

Karlic H, Lohninger A. Supplementation of L-carnitine in athletes: does it make sense? Nut J. 2004; 20: 709715.

Kuroda N, Ohyama Y, Nakashima K, Akiyama S. Determination of carnitine and acylcarnitines in human plasma by means of fluorescence labeling using 2-(4-hydrazinocarbonylphenyl)-4,5diphenylimidazole. Chem Pharm Bull. 1996; 44: 1525-1529.

Leibovitz B, Mueller J. Carnitine. J Optimal Nutr. 1993; 2: 90-109.

Llias I, Manoli I, Blackman MR, Gold PW, Alesci S. Lcarnitine and acetyl-L-carnitine in the treatment of complications associated with HIV infection and antiretroviral therapy. Mitochondrion 2004; 4: 163168.

Longo A, Bruno G, Curti S, Mancinelli A, Miotto G. Determination of L-carnitine, acetyl-L-carnitine and propionyl-L-carnitine in human plasma by highperformance liquid chromatography after pre-column derivatization with 1-aminoanthracene. J Chromatogr B. 1996; 686: 129-139.
Lopes G, Bazotte RB, Curi R, Alves-Do-Prado W. Land DL-carnitine induce tetanic fade in rat neuromuscular preparation. Braz J Med Biol Res. 2003; 36: 1255-1262.

Maccari F, Arseni A, Chiodi P, Ramacci MT, Angelucci L, Hulsmann WC. L-carnitine effect on plasma lipoproteins of hyperlipidemic fat-loaded rats. Lipids 1987; 22: 1005-1008.

Malaguarnera M, Restuccia S, Di Fazio I, Zoccolo AM, Ferlito L, Bentivegna P. Serum carnitine levels in chronic hepatitis $\mathrm{C}$ patients before and after lymphoblastoid interferon-alpha treatment. Biodrugs 1999; 12: 65-69.

Malone JI, Schocken DD, Morrison AD, GilbertBarness E. Diabetic cardiomyophaty and carnitine deficiency. J Diabetes Complications 1999; 13: 8690.

Mamoulakis D, Galanakis E, Dionyssopoulou E, Evangeliou A, Sbyrakis S. Carnitine deficiency in children and adolescents with type 1 diabetes. $J$ Diabetes Comp. 2004; 18: 271-274.

Marzo A, Corsico N, Cardace G, Morabito E. Effect of acetyl-L-carnitine treatment on the levels of levocarnitine and its derivatives in streptozotocindiabetic rats. Arzneimittelforschung 1993; 43: 339342.

Paulson D, Shug A. Tissue specific depletion of Lcarnitine in the rat heart and skeletal muscle by Dcarnitine. Life Sci. 1981; 28: 2931-2938.

Pola P, Tondi P, Dal Lago A, Serrichio M, Flore R. Statistical evaluation of long-term L-carnitine therapy in hyperlipoproteinaemias. Drugs Exp Clin Res. 1983; 9: 925-935.

Proulx F, Lacroix J, Qureshi IA, Nadeau D, Gauthier M, Lambert M. Acquired carnitine abnormalities in critically ill children. Eur J Pediatr. 1997; 156: 864869.

Rajasekar P, Anuradha CV. Effect of L-carnitine on skeletal muscle lipids and oxidative stress in rats fed high-fructose diet. Exp Diabetes Res. 2007; 2007: 18.

Rebouche CJ. Carnitine function and requirements during the life cycle. FASEB J. 1992; 6: 3379-3386.

Reddi AS, Jyothirmayi GN, De Angelis B, Frank O, Baker H. Effect of short- and long-term diabetes on carnitine and myo-inositol in rats. Comp Biochem Physiol. 1991; 98: 39-42.

Rodrigues B, Seccombe D, Mcneill JH. Effect of oral L-carnitine treatment on lipid metabolism and cardiac function in chronically diabetic rats. Can J Physiol Pharmacol. 1990; 68: 1601-1608.

Rodrigues B, Xiang H, Mcneill JH. Effect of Lcarnitine treatment on lipid metabolism and cardiac performance in chronically diabetic rats. Diabetes 1988; 37: 1358-1364. 
Shimura S, Hasegawa T. Changes of lipid concentrations in liver and serum by administration of carnitine added diets in rats. J Vet Med Sci. 1993; 55: 845-847.

Siqueira VLD, Cortez DAG, Nakamura CV, Bazotte RB. Pharmacological studies of cordia salicifolia cham in both normal and diabetic rats. Braz Arch Biol Technol. 2006; 49: 215-218.

Tanaka Y, Sasaki R, Fukui F, Waki H, Kawabata T, Okazaki M, et al. Acetyl-L-carnitine supplementation restores decreased tissue carnitine levels and impaired lipid metabolism in aged rats. J Lipid Res. 2004; 45: 729-735.

Vacha G, Giorcelli G, Siliprandi N, Corsi M. Favorable effects of L-carnitine treatment on hypertriglyceridemia in hemodialysis patients decisive role of low levels of high-density lipoprotein-cholesterol. Am Clin Nutr. 1983; 38: 532540.
Vary TC, Neely JR. Characterization of carnitine transport in isolated perfused adult rat hearts. Am $J$ Physiol. 1982; 242: 585-592.

Wieland $\mathrm{OH}$, Deufel T, Paetzke-Brunner I. Free and esterified carnitine: colorimetric method. Editors: $\mathrm{H}$. U. Bergmeyer. In: Methods of enzymatic analysis. New York: Academic Press; 1985. 481-488.

Yokogawa K, Miya K, Tamai I, Higashi Y, Nomura M, Miyamoto K, et al. Characteristics of L-carnitine transport in cultured human hepatoma HLF cells. $J$ Pharm Pharmacol. 1999; 51: 935-940.
Received: October 29, 2010; Revised: March 30, 2011; Accepted: September 12, 2011. 